\title{
Efforts to Overcome Procrastination through Individual Construction Using Self-Introspection Methods in Achieving Santri Scholarship Program Students (PBSB)
}

\author{
A L Afiyatin \\ Islamic Counseling Guidance Concentration, \\ Interdisciplinary Islamic Studies (IIS) Study Program, \\ Postgraduate UIN Sunan Kalijaga Yogyakarta \\ Email: alfiyahlaila1@gmail.com
}

\begin{abstract}
The purpose of this article is to find out the description of student procrastination and the implications of counseling individuals with self-introspection techniques to overcome procrastination. This research was conducted on seventh semester Santri Achievement Scholarship Program (PBSB) students, data collection techniques were carried out by interview and observation. Subjects were 7 students and special subjects for in-depth interviews of 3 students, with the aim of deep meaning. The results of the study and discussion are that the general picture of student procrastination can be seen from postponement, laziness, and delay. While the impact of the application of self-introspection (muhasabah) by students in overcoming procrastination is to reduce procrastination, which is evident from the following indicators: first consideration before taking action, careful on activities that are priority, create better change.
\end{abstract}

Keywords: procrastination; individual counseling; self-introspection

\section{INTRODUCTION}

The obligation to pay attention to time for each Muslim is based on discipline [1]. Time as a fundamental need and at the same time binds the entire relay of human life, time must be considered and used as well as possible. Obligation to pay attention to time for every Muslim must pay attention to several things. First, keep the benefits of time. Second, do not waste time. Third, fill in the blanks of time with various useful activities. Fourth, competing in goodness, and fifth, always learning from travel day after day and time after time [1].

In fact, some humans have experienced gaps in managing time, which in the psychology literature is called procrastination. Procrastination is an indiscipline behavior [9]. Procrastination is a special form of procrastination [11], Procrastination is viewed from deliberate delays [12]. Delay as a counter-productive activity [17] has occurred in various fields, both in academic, social and career [10].

Not surprisingly, the study of procrastination attitudes has not subsided until now, even showing the attitude that always brings the flow of self-defense throwing, with reasons because there is less time to complete tasks, forget the responsibilities that must be fulfilled, and enjoy other activities that make it happier. 
In reviewing procrastination, several aspects need to be considered. Among other things are the factors that influence it, namely 1) Fear of failure, which includes anxiety and low self-confidence, and 2) Adversiveness and laziness, which includes low energy that does not want tasks [20]. Aspects in procrastination are delay, 2) delays, 3) gaps, and 4) Doing other activities that are more pleasant [9].

Paying attention to time is certainly needed by students for the best possible education process, one of them is students who get scholarships from the Ministry of Religion, namely the scholarship program for outstanding students (PBSB). There are certain demands that must be achieved in maintaining more value as outstanding students (Ghozali, 2018), trying better (DSN, 2018), one of which is discipline in utilizing time. But in reality, there are some of them who pay less attention to their time.

Academic procrastination among students shows a high category [14]. The results of the Problem Check List (DCM) analysis show that the prominent problems of the habits in learning students are delays in fulfilling responsibilities [15]. Procrastination is reflected in the habit of being late to class, being late in collecting assignments and even reaching suspended report cards [19]. Not surprisingly, procrastination studies have not subsided until now, even showing a significant attitude.

The process of overcoming procrastination can be overcome through the improvement of time management skills through cognitive engineering training programs (planning, problem solving, and self-instruction), which show a better change in managing time, with the dominant influential technique being self-intruction [6], or group counseling with a beavioristic approach [18], and / or reality counseling [5].
Developing idealistic attitudes and values for clients is important, because frame of religious reference is expected to be a controller of all activities in life [1]. Therefore, the philosophical basis of applying introspection in counseling is to demand an active role from the client. In Islamic psychology, the concept that occurs in self becomes a fundamental aspect [22], if the client is able to actively participate in the counseling process, he will hear his own advice, so he is easy to overcome procrastination.

Introspection has been applied in various fields, which are believed to be a form of evaluation, which is called call from self, which is an instinctive call to oneself. As an important dimension, this technique needs to be applied when counseling takes place, so that individuals are helped and directed to change attitudes [17], starting with selfcontrol [24], which involves spiritual aspects [21], and existence understanding of transcendental values [13] in the spirit meaning. So, procrastination as a psychological problem must be addressed by looking at themselves.

The consequence of self-introspection is going up on the ladder to upgrade. An effort to self-audit to fit the potential level towards as noble quality as possible [2]. Giving birth to a calm mind, clear goals, and feeling healthy that is responsible, then a person will feel strong, competent, and competent in overcoming his personal problems [4].

The implications of individual counseling services for someone are as an effort so that the process of individual development runs with a linear flow with expectations and values that apply to self and the environment, so that it appears in someone about the superior nature and ability to solve problems [17].

The counseling process must be considered to be applied systematically by the counselor, namely: 1) The initial stage, which includes the creation of rapport 
(meaningful counseling relationships). 2) In the middle stage, the counselor strives to get clients involved and open, explore and explore problems. 3) The final stage of counseling or action as well as evaluation, namely when there is a change in the client in a more positive direction and has a planned life, and finally the counseling session is closed by the counselor [25]. While in self-introspection are: planning, implementation, examination, and improvement [3]. Self-introspection has integration with the aim of individual counseling as tarapeutic assistance directed at changing attitudes and behavior [17].

The impact, there is a strong commitment in the experience of values of faith, understanding the rhythms of life, responsibility, and being able to resolve conflicts [16]. The active role of the client is directed at behavior, effectiveness, and attention in responding to the demands of self and the environment [23], which involves planning, organizing, directing, monitoring, and celebrating victory [24]. So that the problem of procrastination related to self-management (uncontrol) can be overcome by self-introspection (muhasabah) as a method that has a value of integrity.

This study aims to explore the description of PBSB student procrastination and the implications of giving counseling individuals with self-introspection techniques to overcome procrastination, with the following framework:

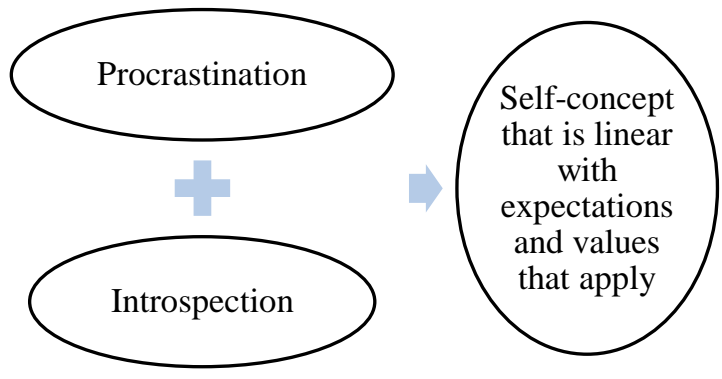

Figure 1. Thinking Framework

\section{RESEARCH METHOD}

This research is a qualitative research approach to counseling practice, by integrating between the literature and the field with the subject of 7 students Achieving Santri Scholarship Program (PBSB). The subject criteria are; 1) Student Achievement Santri Scholarship Program (PBSB), and 2) Semester VII. This study aims to determine the implications of counseling individuals with self-introspection techniques in overcoming procrastination, by focusing on the point of view of student expressions about self-concepts that dynamically experience the process of self-introspection.

Data collection was conducted face-toface interviews, and analyzed with a descriptive-narrative approach and assisted by using tables and images to better visualize field findings, conducted through a series of active interview procedures in understanding procrastination phenomena, collecting procrastination completion data from statements from 7 students and supporting data through relevant article journals.

\section{RESULT AND DISCUSSION}

In general, students experience a time gap (procrastination), even with different levels. This shows that students have diversity in processing time. Among the factors that become the point of difference is the concept of self in carrying out all activities, both related to academics in general or various personal activities.

Students in the seventh semester of santri have 2 categories of time management, which are moderate and high in paying attention. In general, their understanding of time management is considered as a self-rule that sometimes changes intentionally because of a factor. There is an understanding of students about time management, but they do not suppress themselves until rigid, as the visualization of the following picture, 


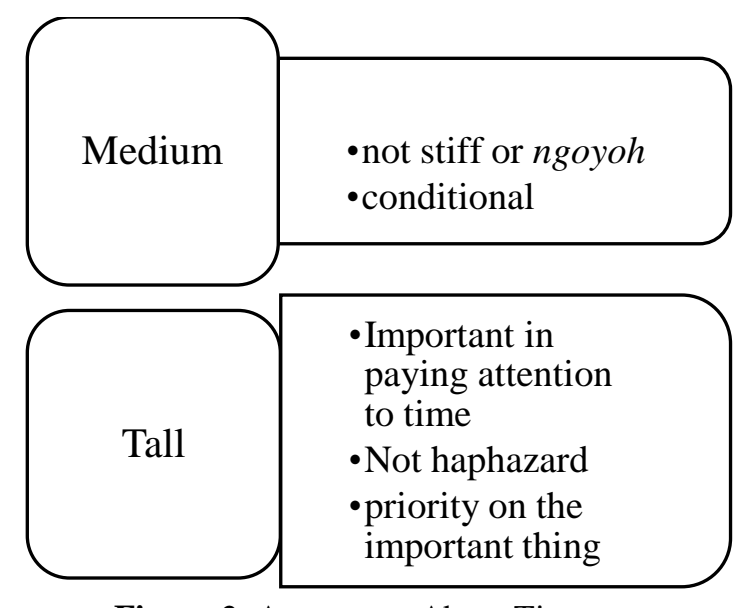

Figure 2. Arguments About Time Management

In the individual counseling process three stages are carried out. Namely: First, establish a close relationship and explore and define the problem. In the process, the client is slowly invited to be aware of and understand the problems that have been or have been experienced, which are explained in the detailed explanation below.

\section{A. Procrastination}

Procrastination is a behavior that shows indiscipline in the use of time, both in starting and when completing work as a whole [9]. Among the small examples that are often carried out by some respondents include delaying work in conditions of leisure, being late in collecting assignments and late in class. As the expression of the following respondents;

"If there is an assignment, I do it, but it depends on the mood. Anyway, I definitely collect tasks "(EF: 2018).

"Learn if there is an exam, even though it's a bit annoying. Hehe ... But it's already normal "(AND: 2018).

"Do the work if there is free time, even though the collection deadline is still long (DSN: 2018).

In addition to these statements, the characteristics that show procrastination from respondents' answers include: 1) Making delays in activities that affect learning activities (late leaving college, entering class, and collecting assignments), 2) Choosing other activities that are more enjoyable, 3 ) Lazy start, and 4) Anxious attitude [7] is excessive

For someone who has good spiritual intelligence, they will have transcendent skills in carrying out their obligations as a student [6]. Using the potential possessed to solve life problems, which are involved in the impact felt after doing a job, namely responsiveness, respect at all levels of consciousness, in rhythm in facing external responses [8].

\section{B. Self-introspection}

After the problem has been explored and described, the next step is the work phase. Before the instruction to do selfintrospection is done, the researcher first captures the initial solution that has been done by the student. One of the responses of respondents in overcoming procrastination is applying short notes about important agendas and tasks that must be completed.

"I made a written alarm in the form of short notes so it wasn't too late. The problem is often seen that way. (DAP: 2018).

Procrastination is closely related to selfconcept that needs to be improved. As a problem that arises from internal factors and dominant factors, action needs to involve individuals as the main actors, namely selfreflection [21]. Because the main actors in practice are the clients themselves, the practice of self-introspection continues whenever and wherever. The indication is as an activity that continues towards better change and invites oneself to start creating attitudes to pay attention to time.

Actually, simple self-introspection has been practiced by students, with an indicator of immediate remorse when the time comes for the completion of a task and the individual must immediately finish. The form of self-calculation performed by students when faced with a time gap is anxiety, awareness, and regret. 
In the practice of self-introspection, systematic stages carried out by three students include: 1) Giving statements about losses by examining why these losses could potentially be experienced, 2) Finding solutions to procrastination, and 3) Paying attention to time. Broadly speaking, the stage passed is correct. If someone cannot have personal advice, it is likely that advice from anyone and in any form will be difficult, even to rejection. Then, yourself acts as the main actor in introspection.

The stage of self-introspection as a strategy in overcoming procrastination, attitudes that can be carried out by individuals are: 1) Consideration before making delays, delays, and gaps, 2) Priority on activities that are obligatory and needed, 3) Careful about prohibitions, and 4) Doing repair. Self-reflection has an important position in overcoming procrastination in the scope of self-concept [17]. Introspection as a suitable practice in overcoming procrastination will certainly have an impact on the expected results. Students can make decisions, choices, plan wisely, and can develop and play a better role in responding to external responses.

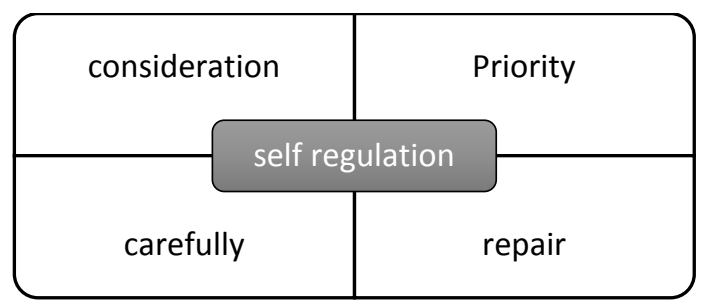

Figure 3. Results of Self Introspection CONCLUSION

The application of self-introspection (muhasabah) by students of the seventh semester Santri Scholarship Program (PBSB) is that individuals can describe procrastination experienced and be able to overcome procrastination. It is evident from the following indicators: There are considerations first before taking action, careful on activities that are priority, creating better change. If the indicators are carried out consistently, students may be able to avoid procrastination.

\section{SUGGESTION}

The application of self-introspection can be applied in all fields, be it education, social, or religion. Therefore, for researchers must do further research in order to get stronger results and also be applied in other fields in order to obtain the conclusion that the introspection of its influence can be accepted as a whole.

\section{REFERENCE}

[1] Amin, Samsul Munir. Bimbingan dan Konseling Islami. Jakarta : Amzah, 2010.

[2] Azhar, Muhammad. Dasyatnya Energi Syukur Istighfar dan Muhasabah. Solo : Al-Kamil, 2014 .

[3] Bachrun, Syaifuddin. Manajemen Muhasabah . Bandung: Mizan Pustaka, 2011.

[4] Center, Academic Skill. Understanding Procrastination. California: Polytechnic State University, 1984.

[5] Christiana, Linda Kurniawati \& Elisabeth. "Penerapan Konseling Realita untuk Mengurangi Prokrastinasi Akademik Siswa Kelas XI IIS SMAN Menganti." Jurnal BK UNESA Vol. 8, No. 1, 2018: 125-131.

[6] Chudari, Ima Ni'mah. "Peningkatan Keterampilan Pengelolaan Waktu Mahasiswa Melalui Program pelatihan dengan Teknik Kognitif." Ilmiah Mitra Swara Ganesha, 2017: 6.

[7] Enung Hasanah, dkk. "Indonesian Adolescents Experience of Parenting Processes that Positively Impacted Youth Identity ." Journal of The Qualitative Research, 2018: 499-512.

[8] Hanafi, Yusuf. "Urgensitas Manajemen Waktu dalam Pendidikan Spiritual Anak." Palestren, 2015: 181.

[9] Hervi, Aliyah Norr \& Iranita. "Hubungan Antara Kontrol Diri dengan Prokrastinasi dalam Menyelesaikan Skripsi pada 
Mahasiswa Universitas Muara Kudus ." Jurnal Psikologi Pitutur Vol. 1, No. 2, 2011: 65-71.

[10] Iven Kartadinata, Sia Tjundjing. "I Love You Tomorrow : Prokrastinasi Akademik dan Manajemen Waktu." Journal of Indonesian Psychological Vol. 23, No. 2, 2008: 109-119.

[11] Jiao, Qun G. "Academic Procrastination and The Peformance of Graduate-Level Cooparative Groups in Research Methode Course." Scholarship of Teaching and Learning Vol. 11, No. 1, 2011: 119-138.

[12] Khusnul Ika, Muhammad As'ad. "Manajemen Waktu, Efikasi Diri, dan Prokrastinasi." Psikologi Indonesia Vol. 2, No. 3, 2013: 217-222.

[13] Kuntowijoyo. Islam sebagai Ilmu : Epistimologi, Metodologi, dan Etika. Yogyakarta: Tiara Wacana, 2007.

[14] Muyana, Siti. "Prokrastinasi Akademik Di Kalangan Mahasiswa Program Studi Bimbingan dan Konseling." Jurnal Counsellia Vol. 8, No. 1, 2018: 45-52.

[15] Nurhidayati, Diana Dwi. "Peningkatan Pemahaman Manajemen Waktu melalui Bimbingan Kelompok dengan Teknik Problem Solving pada Siswa." Psikopedagogia, 2016: 25-31.

[16] Nurihsan, Syamsu Yusuf. Juntika. Landasan Bimbingan dan Konseling . Bandung: Remaja Rosdakarya, 2005.

[17] Nursalim, Muhammad. Bimbingan dan Konseling pribadi Sosial. Yogyakarta: Ladang Kata, 2013.

[18]Puswanti. "Upaya Merdeuksi Prokrastinasi Akademik Melalui Konseling Kelompok Melalui Pendekatan Behavioristik pada Siswa SMK ." Jurnal Psikopedagogia Vol. 3, No. 1, 2014: 11-19.

[19] Rizki, Laila. Hubungan Motivasi Berprestasi dengan Prokrastinasi Akademik Siswa MAN III Yogyakarta. Yogyakarta : UIN Sunan Kalijaga, 2015.

[20] Rothblum, Laura J. Solomon dan Esther D. "Academic Procrastination :
Frequency and Cognitive-Behavioral Corralates ." Counseling Psychology, 1984: 507.

[21] Sholihin, Mukhtar. "Signifikansi Tasawuf : Solusi Pencarian Makna Hidup." Jurnal Syifa al-Qulub Vol. 1, No. 1 , 2016: 1-7.

[22] Skinner, Rasid. "An Islamic Approach to Psychology and Mental Health." Journal of Mental Health, Religion \& Culture Vol. 13, No. 6, 2016: 547-551.

[23] Subandi, Lisya Chaerani dan. Psikologi Santri Penghafal Al-Qur'an " Peran Regulasi Diri". Yogyakarta : Pustaka Pelajar, 2010.

[24] Sutarto, Edi. Pemimpin Cinta. Bandung: Kaifa, 2015.

[25] Willis, Sofyan S. Konseling Individual : Teori da Praktek. Bandung : Alfabeta, 2014. 